\title{
Just a foreword? Malinowski, Geertz and the anthropologist as native
}

\author{
Stefano Montes \\ University of Palermo, Italy, and University of Tartu, Estonia \\ Ülikooli 17, 51014 Tartu, Estonia \\ e-mail: montes.stefano@tiscalinet.it
}

\begin{abstract}
Read through semiotic analysis, the narrative intrigue of (the evenemential and cognitive dimension of) the anthropologist's work reveals the epistemological configuration encasing some central and interrelated questions in anthropology: the communication-interaction between anthropologists and other inter-actants, their invention-application of some metalanguages and the subsequent intercultural translations of concepts and processes. To explore this configuration, I compare a foreword written by Malinowski and another one written by Geertz. In these forewords, they resort to refined stories to frame complex argumentations. In Malinowski's foreword, two superposing stories are told: (1) a tale of a subject's performance newly endowed with professional competences (the ethnologist) and a discipline possessing a more modern and positive knowledge (Functionalist ethnology) and (2) a symmetric tale of exchanged messages (with relative sanction and counter-sanction) between an enunciator (who has to lay the foundations of this science) and an addressee (who has to confirm the validity of messages). To lay these foundations, the enunciator implicitly proposes an epistemology based on some values (such as 'penetration', 'progression', and the 'overcoming of limits') privileging the metaphor of space and the cumulative aspect of process. As far as Geertz's foreword is concerned, the enunciator has recourse to two different stories: (1) one concerning the interaction between Geertz and his editor (rather than with natives) to justify his hermeneutic position and (2) another one, larger and including, concerning the reversal of causality relationships to reaffirm the value of coincidence. If in Malinowski's foreword, stories are used to redefine some programmatic principles ('discontinuity' and the combination of 'three different oxymora') through which ethnology can be given a scientific nature and a new foundation, in Geertz's foreword, on the contrary, value is given to 'coincidence' and 'writing' in its multiple forms and (paradoxically, for an interpretativist) a binary discursive epistemology and a style of thought privileging the nonterminative and imperfective process have been combined.
\end{abstract}




\section{Stefano Montes}

Even if a beginning is the inevitable start of a positive project, I would like to begin by affirming a negation and by weakening a programmation. This text is not the exact transcription of the conference that I presented at the congress on Anthropology and Semiotics that took place last year in Tartu (whose proceedings can be found in this volume). The original title of my communication was Towards a Semiotics of Anthropology and Anthropology of Semiotics. I had to cut parts off my original communication because of more limited space granted for written texts. The risk was to undermine the value of the chaotic flux of the fortuitous coincidence and to lose the fresh and necessary taste of what was said during the oral communication. I eliminated a part of the communication that concerned the anthropology of semiotics and I decided to concentrate on the semiotics of anthropology. This necessity, motivated here by practical reasons, is a theoretical and unavoidable component of any anthropological project and deserves a thorough examination. This necessity passes, in my individual project, as a reflecting reverberation concerning the impossibility to recover the whole process (the enunciation in its effective unfolding and the practice in its development) and the possibility to eliminate, at will but without damage, some elements of the organization of the message to be conveyed (the superfluous remainders of the utterance and the redundant constituents of the abstract metalanguage).

Can anthropology of semiotics be considered, in its complex whole, a superfluous remainder? I would not say so. I would rather say it is a necessary reference inside other referring elements whose series create a grid of meaning, a mythical ground upon which one can situate a transitory origin of impalpable relationships existing between subjects and objects. By creating multiple references (and by implanting grids), one can hope to better focus on an (apparent transparent) object to study and on the (apparent public) meanings assembled by private subject carrying out researches. By combining references and grids, one can disarm the traps of transparency and the illusions of 'pre-shared-once-for-all' meanings.

Lévi-Strauss had already had the insight that references and grids were the base of the constitution of myth and even founded the 
meaning of life ${ }^{1}$. Following his example concerning myth and life (as well as the principle of constitution and foundation of a scientific elaboration), I reserve the right to start here a reflection on the semiotics of anthropology and to refer in the future to the anthropology of semiotics. I am, as a consequence, in the passive position of someone who concentrates on the semiotics of anthropology as if it was a central element, but who does not either forget that, at the same time, the act of relegating in the periphery (the anthropology of semiotics, in this specific case) is only occasional and it is not tantamount to the recognition of a substantial Otherness or an ultimate meaning. It is a question of balancing Self and Otherness: 'keeping oneself' on the threshold, 'running after' a reference and 'holding back' on the structuring of an unfolding grid. The programmation and the random intervention, the necessity and the coincidence, the part and the whole, the enunciation and the utterance, the theories and the practices, the subjective investment and the transparent objectivity, the reference and the grid are some categories that inescapably cross one another and intermingle in the (re)presentation of a past event (including oral communication).

Most of the work of an anthropologist is situated on the brink between a 'past event' and the 'event to represent', between a 'message to convey' and the 'fleeting enunciation to recover'. That is why he cannot help thinking as a linguist and a semiotician or improvising himself as a philosopher of daily life driving off those abstractions that introduce themselves, furtively and restlessly, in the grain of experience to be converted into texts. An anthropologist does his work, implying himself thoroughly and using his personal experience, to obtain a more general and systematic knowledge on Man and a more specific and concrete knowledge on men. Independently from

\footnotetext{
1 'Dans tout ce que j'ai écrit sur la mythologie, j'ai voulu montrer qu'on n'arrive jamais à un sens dernier. Y arrive-t-on d'ailleurs dans la vie ? La signification que peut offrir un mythe pour moi, pour ceux qui le racontent ou l'écoutent à tel ou tel moment et dans des circonstances déterminées, n'existe que par rapport à d'autres significations que le mythe peut offrir pour d'autres narrateurs ou auditeurs, dans d'autres circonstances et à un autre moment. Un mythe propose une grille, définissable seulement par ses règles de construction. Cette grille permet de déchiffrer un sens, non du mythe lui-même mais de tout le reste: images du monde, de la société, de l'histoire, tapies au seuil de la conscience, avec les interrogations que les hommes se posent à leur sujet" (LéviStrauss 1988: 197).
} 
his effective declinations of the discipline (for example, a preference for abstraction or for concreteness), his belonging to a precise school of thought or a more autonomous approach, the recourse to experience remains constant and indispensable.

Nevertheless, any experience becomes an accessory component (somewhat elusive) if it is not rendered through its codification and communication. Even though the recourse to experience is inevitable, an anthropologist could not produce the 'results' of his research without a text that concentrates (and at the same time eliminates) part of the situations and interactions that he had directly on location. Any experience has to be converted in ordered semiosis and has to be supported by a comprehensible text for a receiver. Similarly, a conference given in a specific context, with a real audience, in conditions of effective interaction, has to be 'adapted' for a larger audience, following modalities that belong, for example, to the written language (which codifies experience in its own terms). Experience cannot be conveyed as such, and neither would be useful if it were possible: 'to take shape', experience needs a supplementary and founding passage consisting in the 'constitution' of a discursive order (Foucault 1971).

In my opinion, the opposition characterising the anthropologist's work, caught between the poles of experience and the order of narration to his readers (and to himself), is, more generally, a founding principle in anthropology that cannot be solved in one sense or another. It is because this opposition is conflicting and unsolved that the anthropologist's work is an interesting object of study. All the more so since this function established between experience and narration is amplified by the implicit role of translator fulfilled by an anthropologist: he translates processes and conceptualisations connected to experience into narrations for an 'arrival audience' often different, by language and culture, from the 'source audience' (Montes 2000-2001). In this perspective, it doesn't sound excessive to stress the syncretism of the roles by saying that an anthropologist is also, even if unconsciously, a semiotician who passes from one code to another, from an oral language to the written one, from a concrete situation to the metalinguistic formalization, from a context to the text, from a cultural semiosphere to another.

I spoke of an 'anthropologist' (and not of 'anthropology') for a concrete reason. An anthropologist is a man (or a woman) who thinks and acts, suffers and has emotions as any other human being. 
Anthropology is on the contrary a discipline that (as most disciplines) tends to abstract the concrete dimension connected to experience and tends to produce "un principe de contrôle de la production du discours" (Foucault 1971: 37). In my contribution, I will neglect anthropology as a generalized knowledge and I will take into account the production of the anthropologist's discourse starting from his individual 'saying' and 'doing': that is a scholar, with a specific competence and background, but also a subject, similar to anyone else, who goes through an exceptional experience such as the ethnographic research.

It is true that an anthropologist cannot escape the principles that, in one period or another of history, dominate in a culture and are transformed into a stereotyped and generalized knowledge. This affirmation, however, more than a real objection is a solid reason to concentrate on single anthropologists and on their specific usage of discursive forms, on their textual representation of the context, on the most adapted metalanguage chosen to investigate Otherness in ethnographies (Montes 2005a). I prefer, therefore, to focus on some anthropologists rather than on anthropology because in this way one can better take into account the specific evenemential and cognitive dimensions of their discourses (Greimas 1983). As we shall see later, the detailed analysis of evenemential and cognitive dimensions is essential to understand the general configuration of the anthropologists' knowledge as a plot of thought, action and emotion.

There is also another reason which justifies my semiotic perspective. If we cannot deny that an anthropologist is an 'author' (Geertz 1988) or, better, the crystallisation of an author-function (Foucault 1994 [1969]), then neither can we neglect that an anthropologist is also a native. In my contribution, I will try to show that an anthropologist is also a native, a member of his own culture in constant balance between intercultural 'objectivations and dialogisms' (Miceli 1990). An anthropologist is an individual born in an exact place, who has learned one or more languages, follows specific customs, respects some laws and refuses others, someone with habits and manners typical of the culture he belongs to. The consequence is that an anthropologist's viewpoint on some cultures usually reveals important features characterizing these cultures but it also reflects his cultural origin and belonging. What I propose here, even if in a short and experimental form, is to study anthropologists as natives: that is 
members of their own culture who cannot help being centred on their culture and, in the meantime, who try to integrate themselves into the culture they are studying.

Following Foucault (who, nevertheless, concentrated more on the notion of author), one can presuppose that an anthropologist's belonging (his 'being native') constitutes, in an archaeological dimension of knowledge, a real and true function that I will call 'nativefunction'. In the history of anthropology, the features representing an anthropologist as a native (with his cultural belonging and individual predisposition) are often omitted, and with it are occasionally cancelled those unsolvable (and necessary) oppositions that, more generally, characterize anthropology: the combination of experience and narration, the tension between individual research and the whole definition of a culture, the relationship between processes and structures, the objectifying work and the subjective investment. I think, more particularly, that an anthropologist's research is effectively marked by a semantic figure: the oxymoron.

The multiple paths of realisation, neutralization or cancellation of conflicting categories, in the form of a cognitive and evenemential intrigue taken into account by an anthropologist, specify the approaches and orientation of different schools in anthropology. Since I cannot explore the cognitive and evenemential dimensions (contained in thick ethnographies) that would reveal the singular usages of these features, I will resort to a shortcut that is in itself a neglected itinerary in semiotics and in anthropology: the analyses of forewords ${ }^{2}$. My choice is therefore intentionally restricted to two texts written by two famous anthropologists: Bronislaw Malinowski and Clifford Geertz. If it is true that these anthropologists are internationally known and that references to their ethnographies are countless, it is also true that their forewords have never been analysed comparatively to show the metadiscursive nature of their reflection and their epistemological positioning (sometimes implicit) contained in very short texts.

2 For practical reasons, I restrain here the analysis to texts without taking into account the subsequent discourse of anthropologists and informants on their own ethnographies and forewords. An anthropology of anthropology questioning itself on the connections between 'what has already happened' and the 'reflection $a$ posteriori' of anthropologists on their work is a research that should become an integral part of a larger program centred on the exploration of the native-function. 
Perhaps, one might wonder why a semiotician should focus on short forewords rather than choosing to analyse the general thought and practice of anthropologists. The motivation is deeply rooted in a semiotic posture: forewords are a concentrate of key concepts and these concepts are situated in these texts that are, as a matter of fact, a real and true genre (Taverna 2006). Analysing a foreword means to study a textual genre and, in parallel, (as stressed by Greimas in his article on the foreword by Dumézil) what the author "lui-même pense de son discours, de sa finalité et de son organisation" (Greimas 1983: 174). This theoretical attitude is based on the postulate that concepts and texts are tightly connected and that the textual genre contributes to assign a specific meaning to concepts (Montes 2005b). I start, therefore, by analysing the foreword written by Malinowski (1922a [1921]) to pass later on to the foreword written by Geertz (2000).

Malinowski's text (1922b) is generally considered a founding text in anthropology and, in the meantime, an essential reference for the Functionalist school. Any discipline tries to give itself an origin and a foundation, both 'situated' in some texts considered as classical texts, references for future scholars. Commonly, Malinowski's text is considered a founding text because it marks, conceptually, the passage from the Evolutionist school to the Functionalist school (with the affirmation of participant observation as a distinctive practice). In my perspective, this text by Malinowski is founding because the passage from one school to another is engraved into the text by some narrative and rhetorical strategies that build a simulacrum of a reader, inside the text, whose duty consists in producing a recognition and a sanction on the 'doing' and 'saying' of the enunciator. In other words, this passage from one school to another becomes a value to communicate that the text conveys by means of refined and complex procedures constructing an idea of 'foundation'.

As we shall see, in the foreword by Malinowski the sanction is emitted as a narrative element already acquired, taken for granted by the implied reader whose role consists in crediting (1) ethnology as a positive and scientific knowledge, in confirming the discontinuity existing (2) between the professional ethnologist and the "amateur's work" and (3) between the Evolutionist school and the Functionalist school. Upon these elements ('crediting with a value' and 'situating a discontinuity'), the enunciator builds a different ethnology, a discip- 
line with a scientific knowledge that possesses a 'foundation' and an 'origin'.

In the incipit a 'foundation' is created through the ostentation of a program of research that should be accomplished rapidly (before the natives disappear) and by defining the figure of the anthropologist as a solitary hero. The program of research and the subject (competent to realise it) are two features tightly connected, already in the incipit, to questions equally central according to Malinowski: the scientific foundation of ethnology and the difficulty emanating from the disappearance of its object of study. Malinowski maintains that:

Ethnology is in the sadly ludicrous, not to say tragic, position, that at the very moment when it begins to put its workshop in order, to forge its proper tools, to start ready for work on its appointed task, the material of its study melts away with hopeless rapidity. Just now, when the methods and aims of scientific field ethnology have taken shape, when men fully trained for the work have begun to travel into savage countries and study their inhabitants these die away under our eyes. (Malinowski 1922a: xv)

Malinowski's discourse revolves around the scientific foundation of a kind of ethnology which is seen, in this fragment, as a discipline already possessing the instruments to accomplish its specific mission: studying the savages of faraway countries. The object to study is considered as "material": the natives are not real and true persons with whom to construct some kind of knowledge, but 'motionless individuals' to observe through the lens of ethnology. The figure of the anthropologist, paradoxically, seems to be absorbed by the discipline and its programmatic knowledge. This is justified by the fact that, in a scientific perspective (the one defended by Malinowski), it is not uniquely the value of a single ethnologist to count, with his subjective insights and discoveries, but also the method of the discipline.

In this way, by opening his foreword with this incipit, the enunciator represents ethnology as a science possessing objective and transparent features. The only trace of the ethnologist's presence is revealed, in this incipit, by the syntagm "under our eyes". As a counterpart to the absent figure of the ethnologist, we can find an almost lifeless object to study, "material" for observation, represented by the lexeme "inhabitants". Rather than people to interact with, the inhabitants are considered objects to observe. They are represented as something solid (that could melt), as something material possessing a 
form and a consistency. Even the method of ethnology "take(s) shape" (becoming solid) and the inhabitants "die under our eyes" (liquefying as objects). In other terms, Malinowski's discourse turns around an idea of solidity and presence (owned by the discipline and by the object to observe), while the ethnologist takes on the features of a collective actant and the natives vanish as interacting subjects. In this short incipit, are therefore outlined, through different modalities, three key figures: the (1) ethnologist, the (2) inhabitants and (3) ethnology. If (1) ethnologists are "men fully trained for the work", the (2) Others are "inhabitants" of "savage countries" and (3) ethnology is represented as a discipline with a positive and a well defined knowledge.

On one hand, we see a discipline that has already a constitution, with a "workshop", its "tools" and its "task" and on the other hand we see material (the natives) represented in terms of solidity and presence. The only difficulty perceived by Malinowski is the 'foreseen' disappearance of the native: the material to observe. It is important here to insist on the meaning of the lexeme 'material': something that one can manipulate and examine without a lively resistance. It is a circumscribed and motionless object that doesn't escape the observation of a subject and that demands reduced forms of interactions.

From the linguistic viewpoint, the rapidity of the ethnologist's action and the responsibility with which he is charged are urged in two ways: thanks to the (1) redundancy of the adverbial locutions ("at the very moment when"; "Just now, when") and to (2) the coincidence created between the inchoative aspect of the discipline which is ready to face scientifically his duty (ethnology that "begins" and is ready "to start") and the terminative aspect of the object of study which disappears. Time is therefore conceived as the ethnologist's time: someone who has to hurry up to do his work before the definitive 'death' of the natives.

The insufficient time and the material nature of the object are tightly connected through the isotopy of the 'solidity' and 'visible' that characterises the incipit. Malinowski's usage of some metaphors strengthens this isotopy spread all over the foreword: see for example, "the material of its study melts away"; "these die away under our eyes". Obviously, the semantic features selected for a "discourse of foundation' can be multiple. In this specific case, the enunciator accentuates the passage from a previous phase to the following one 
and emphasizes the figure of a rival, an anti-actant to be discredited: the amateur. Malinowski writes:

The research which has been done on native races by men of academic trainings has proved beyond doubt and cavil that scientific, methodic inquiry can give us results far more abundant and of better quality than those of even the best amateur's work. Most, though not all, of the modern scientific accounts have opened up quite new and unexpected aspects of tribal life. They have given us, in clear outline, the picture of social institutions often surprisingly vast and complex; they have brought before us the vision of the native as he is, in his religious and magical beliefs and practices. (Malinowski 1922a: xv)

The "amateur" fulfills at least two critical roles: he is somebody who lacks the necessary competence to do fieldwork and he is also an antiactant through which one can see, by a negative comparison, what is the real duty of an ethnologist endowed with "academic trainings" and willing to do a "methodic inquiry". If, in the incipit, the accent is laid on ethnology in itself (and on the potential manque produced by the rapid disappearance of the material to study), in this fragment the enunciator focuses more specifically on a new figure of ethnologist who is defined in (1) positive terms and by using a (2) negative comparison: (1) positively, by the syntagm "men of academic trainings" and by the attribution of "results far more abundant and of better quality than those of even the best amateur's work"; (2) negatively, through the discredit of the anti-actant (the amateur) who summarizes a performance and a competence to refuse because (for the enunciator) they are already overcome by modern science.

As we have seen, in order to construct a scientific knowledge Malinowski maintains that there are two moments in the history of the discipline: the first one marked by the amateur's work (those who improvised themselves as ethnologists) and the second one, scientific and modern, dominated by the 'real' ethnologist with a program of research based on some essential elements (for example, method and academic trainings) that characterise his competence and define his performance (with a triple object of value such as "aspects of tribal life", "the picture of social institutions" and "the vision of the native as he is").

By affirming the existence of different periods (and the passage from the first one to the second one), the enunciator obtains a double effect. The enunciator builds a simulacrum of a reader who can 
positively describe the new figure of ethnologist (belonging to the present and to science) to the detriment of the amateurs (belonging to the past and non-science). In the meantime, the enunciator can imply that also all the others who did research before the Functionalists are overcome and did not produce real science. This rhetorical strategy is therefore effective to advance an implicit meaning that could have not been expressed manifestly by Malinowski: the polemics with the Evolutionists. Stressing a difference between what is old and overcome (the amateur) and what is new and modern (the new figure of ethnologist) has also the function to sanction positively a kind of ethnologist (Functionalist) to the detriment of others (for example, the Evolutionists).

Furthermore, if in this fragment the ethnologist's program is more precisely defined, then also the isotopy of the object to be studied as material and seized by observation is also strengthened. In fact, for the ethnologist the "social institutions" become a "picture" and the native becomes a "vision" that is "before us" (the ethnologists). In sum, in this fragment we can find a whole story with a subject charged to act (the ethnologist), an explicit anti-actant (the amateur), an implicit anti-actant (the Evolutionist), a triple object of value ("tribal life", "social institutions" and "the native") and a helper-instrument (the observation).

The tight association between the rhetorical and the narrative strategy helps avoiding an open polemics with the Evolutionists and, more specifically, is effective to convey furtively two fundamental narrative segments: the competence and the sanction. The competence of the subject charged to act (the ethnologist) is seen as if it was the only and exclusive kind of scientific knowledge; the sanction is built as if it was taken for granted, that is a sanction not to verify ("the research $[\ldots]$ has proved beyond doubt and cavil [...]"; "They have given us, in clear outline, the picture of social institutions"). The positive (and anticipated) sanction is the result of a strategy used to obtain (1) the recognition from the reader and (2) the manifest acquisition of two features conferring scientific and natural value: 'clearness' and 'visibility'.

If the role of observation is confirmed both in the incipit and in this passage, what is modified is here the meaning of the object to study. If the object ("the native") was considered as 'material to observe', in this passage the "native" becomes above all (and somehow implicitly) 
a goal to reach through observation. In other terms, it is here implied that the clearness obtained following research and the greater visibility of material correspond to an increment of knowledge. In this way, the enunciator communicates the presupposition that the goal of science does not only consist in the application of the look to material that is "under our eyes", but also in the capacity to make clearer (always through observation), more visible and more objective the material studied. Therefore, the "native" is material that has to be studied initially by the power of observation, but it has also to be transformed to further become a "vision" and a "picture". Even though observation is still present in the initial state ("material") and in the augmentation of knowledge concerning the final stage ("picture"), we see that (in the transformation produced by research and in the passage from one phase to the other) there is an acquisition of two fundamental elements: (1) the material to observe becomes a picture that has the characteristics of a more general and complex whole and (2) the native becomes what he really is, an essence.

A rhetoric of observation is therefore fully confirmed in this analysis of the foreword written by Malinowski. In his ethnographies, it is an effective strategy to affirm the presence of the ethnologist in the field, his 'being there' who persuades the reader that his story is true, but it is also a manner to propose a method of research founded on a real and true contemplative epistemology and on an inductive method (Kilani 1990). What is even more stunning is that, at least in this foreword, observation has two values: it is used to apply to (and to contact) an object and to produce a transformation of this same object. This transformation is a synonym of knowledge. This knowledge is the result of a procedure that, just because it is built on the hermeneutic power of observation, (1) eliminates the problem concerning the complicated interaction with the native and (2) affirms an episteme typical of western thought. Even though Malinowski is considered the father of participant observation, this oxymoron, at least in this foreword, is solved in favour of observation while the native, rather than an individual with whom to interact, is seen as an object to observe. As far as the western episteme (implicitly suggested by Malinowski) is concerned, we can say that it is founded on observation as an instrument of truth and on the augmentation of knowledge obtained through the application of observation that reveals the interiority (and the essence) of things. The 'truth' advanced by this kind of western 
knowledge is associated to (1) visibility as a whole ("picture"), to a (2) static object ("material") and to a (3) penetration of the external façade in order to bring (a) what is the internal ("mind") to the (b) external surface ("the native as he is").

This association is even stronger in the following passage of the foreword:

They have allowed us to penetrate into his mind far more deeply than we have ever done before. (Malinowski 1922a: xv)

By reading these lines, one realizes that it is not only a question concerning the way an ethnologist shows himself (on location and in the text he writes) and how he sees his object (his conception of Otherness). More specifically, in this foreword, an implicit knowledge 'passes' underneath the appearance of a newly conceived discipline. This fragment is, therefore, fundamental because it solves (or tries to solve) an implicit oxymoron lying in the ethnologist's program based on the difference (and association) between the categories subject/ object and external/internal. Initially, the native is de-subjectivised and becomes material to be observed for a subject (the ethnologist); afterwards, observation allows the ethnologist to overcome the frontier separating the 'external envelope' and the 'internal essence' and to penetrate into the depths behind the surface in order to bring outside what was hidden. The (apparent) paradox is that, initially, it is given value to the external object (corresponding to de-subjectivation); afterwards, it is given value to what, logically, could not be seen: the internal essence.

Even though both themes are dear to western tradition ("penetration into an interior' and 'valorisation of essence'), the originality of Malinowski's approach consists in the association of the conflicting terms (the oxymoron) and in its development into a narrative syntagm that transforms the paradigms that constitute it (subject/object; external/internal) into a powerful instrument of knowledge: that is a story in which 'observation' is an instrument of knowledge and, in the meantime, it is a semantic operator of essences into visible materials that keep an 'essential' value. What has to be underlined is that this transformation of the oxymoron (of knowledge into a narrative intrigue) precedes and implies another, more famous oxymoron: the participant observation and the rhetoric of the ethnologist's presence as a truthful saying. To say this differently, the oxymoron regarding 
participant observation is the result of a more basic oxymoron: the desubjectivation of the native (subject $\rightarrow$ object) and the 'penetration' into the internal depths of his mind (external $\rightarrow$ internal). In the foreword, the resolution of this oxymoron remains conflicting because, on one hand, the ethnologist's observation is equally a means to seize 'what is outside' (based on the couple subject/object) and 'what is inside' (based on the couple external surface/internal mind) and, on the other hand, participation (even if less important than observation) demands somehow the recognition of the status of subject to the native.

One can suppose that this specific organization of the oxymoron is both the outcome of Malinowski's belonging to western culture and the fruit of his originality. In this perspective, the passage from an improvised ethnology (the amateur) or an old-fashioned ethnology (the Evolutionist) to a professional ethnology is not as marked as Malinowski would like to make us believe in the incipit. Firstly, because the relationship between observation and participation is not obvious. Participation and fieldwork, usually considered innovative elements introduced by Malinowski ${ }^{3}$, are actually dependant on the observation of a subject who does not fully seize, in the field, the dynamism of Otherness, and 'carries' elsewhere (geographically, in far-reaching locations) the spirit of the laboratory research of the nineteenth century European man. Secondly, the "picture" that Malinowski would like to seize (culture as a whole to study in itself) has also the goal, more typical of Evolutionism, to take into consideration, through the primitive, the origin of Man. The native's Otherness, then, rather than a whole composed of parts with constitutive rules, is transformed into a sort of 'originally degraded identity' of mankind, an object (the native) lagging behind in the history of evolution:

From the new material scientifically hall-marked, students of comparative Ethnology have already drawn some very important conclusions on the origin of human customs, beliefs and institutions; on the history of culture, and their

\footnotetext{
3 For a critical discussion concerning this point and the parallel importance of history that 'situates' the researcher in time and space see Valeri 2002. For a further development on the related question concerning subjectivity in anthropology and in some related fields see Buttitta 2003.
} 
spread and contact; on the laws of human behaviour in society, and of the human mind. (Malinowski 1922a: xv)

As shown in this fragment, the polemics with the previous schools and with the amateurs is not centred on a monolithic and exclusive definition of culture. In fact, in the foreword one can see an alternation of at least two definitions: one more functionalist that considers natives as an object to study as a whole constituted of integrated parts and another more evolutionist that conceives the native as a primitive prototype of the man of the past to study to get to conclusions on the origin of modern man and on the evolution that brought mankind from primitive man to civilized man. In other terms, the primitive man is seen sometimes as a man to study as a product of his culture and sometimes as a specimen of the past. Both definitions are not conflicting with two main recurrent features: insufficient time and the power of observation. These features characterize research:

The hope of gaining a new vision of savage humanity through the labours of scientific specialists opens out like a mirage, vanishing almost as soon as perceived. For though at present, there is still a large number of native communities available for scientific study, within a generation or two, they or their cultures will have practically disappeared. The need for energetic work is urgent, and the time is short. Nor, alas, up to the present, has any adequate interest been taken by the public in these studies. The number of workers is small, the encouragement they receive scanty. I feel therefore no need to justify an ethnological contribution which is the result of specialised research in the field. (Malinowski 1922a: xv-xvi)

To realize the importance of these features in the foreword, it is enough to bring to remembrance a few terms belonging to the semantic field of observation ("vision", "mirage", "vanishing", "perceived") and to the temporal axis ("within a generation", "disappeared", "short"). The association between these two elements ('observation' as an instrument of penetration of Otherness and fleeting 'time' as a means to produce acceleration) is not casual. In fact, besides confirming traces of evolutionist thought in the epistemology conceived by Malinowski, this association suggests that the goal of ethnology should consist more in the search of 'essences' to encase in the path of mankind rather than in the study of dynamism and relationship inside a system. Actually, both paths of research, one 


\section{Stefano Montes}

more functionalist and another more evolutionist, intermingle in the foreword and they are not clearly distinguished.

Conversely, in the following passage the implied enunciator speaks for the first time and qualifies himself directly through the first person of the pronoun "I" to communicate, this time with determination, what are the features characterizing Functionalism: fieldwork and a holistic conception of culture. Malinowski points it out:

In this volume I give an account of one phase of savage life only, in describing certain forms of inter-tribal, trading relations among the natives of New Guinea. This account has been culled, as a preliminary monograph, from Ethnographic material, covering the whole extent of the tribal culture of one district. One of the first conditions of acceptable Ethnographic work certainly is that it should deal with the totality of all social, cultural and psychological aspects of the community, for they are so interwoven that not one can be understood without taking into consideration all the others. The reader of this monograph will clearly see that, though its main theme is economic - for it deals with commercial enterprise, exchange and trade - constant reference has to be made to social organisation, the power of magic, to mythology and folklore, and indeed to all other aspects as well as the main one. (Malinowski 1922a: xvi)

To communicate this message, the enunciator feels the need to speak in the first person and to refer overtly to a symmetrical figure: the "reader". As a matter of fact, the reader is intentionally mentioned because he represents the pole of the communication that has to confirm, with his explicit intervention, the 'clearness' and the 'foundation' owned by methodology. Furthermore, the reader is mentioned because he is connected to the refusal of the enunciator to justify his work in the previous fragment of the foreword ("I feel therefore no need to justify an ethnological contribution"). Malinowski refuses to give a justification concerning his own work because he is aware that the interest of ethnographies is limited to a specialized public and he would like, on one hand, to show the legitimacy of these studies and, on the other hand, he would like to open to a larger public and confirm this disciplinary knowledge.

To establish a direct communication between the enunciator and the reader, between a kind of 'doing' and the reception of this 'doing', authorises what has been prospected as a new discipline from the methodological viewpoint. In this perspective, the strategy concerning enunciation goes hand in hand with the rhetorical strategy. The 
positive sanction is emitted from an enunciator who takes for granted to receive an acceptance from the addressee: the sanction of the reader is connected to the performance of the anthropologist-enunciator; the point of view of the reader (who can "clearly see") corresponds to the "account" of the anthropologist. Therefore, if the enunciator speaks as an "I" it is because he addresses to the corresponding figure of enunciation (a "you" represented by the reader) in order to stress the role of solitary hero that he is advocating.

If in the first part of the foreword, method was praised and the birth of a new ethnology founded on a positive knowledge was also proclaimed, in the second part the more specific duty of a subject (who has to accomplish a 'mission' based on some relevant features) is stressed: the solitude of his work, the displacement in a faraway and exotic country, the considerable duration in time, the linguistic competences, the natives' life as a 'spectacle' constantly before his eyes. Nevertheless, even in this segment, living with the natives becomes for the solitary ethnologist, more than a real participation, a spectacle to observe:

The geographical area of which the book treats is limited to the Archipelagoes lying off the eastern end of New Guinea. Even within this, the main field of research was in one district, that of the Trobriand Islands. This, however, has been studied minutely. I have lived in that one archipelago for about two years in the course of three expeditions to New Guinea, during which time I naturally acquired a thorough knowledge of the language. I did my work entirely alone, living for the greater part of the time right in the villages. I therefore had constantly the daily life of the natives before my eyes, while accidental, dramatic occurrences, deaths, quarrels, village brawls, public and ceremonial events, could not escape my notice. (Malinowski 1922a: xvi-xvii)

More generally, the attempt is, on one hand, to obtain the recognition of Functionalism's methodological objectivity (from the implied reader) and, on the other hand to underline the power of penetration into the natives' culture possessed by a subject provided with specific competences. One might say, without exaggeration, that all the foreword tends towards the effacement of the opposition existing, in principle, between a method declared objective and a solitary hero who cannot help being an individual subject (of observation, comprehension, effort, capacity to learn, to resist, and so on). We can easily compare the ethnologist's work (as it is meant by Malinowski) with the process of penetration of the spermatozoid into an ovule. 


\section{Stefano Montes}

Only one spermatozoid (the ethnologist endowed with competences who knows how to face the discomfort of life among savage peoples) has the privilege to penetrate into the ovule (the natives' culture). In both cases (the spermatozoid and the ethnologist), the mission can be considered accomplished if they overcome the barriers separating the 'external space' from the 'internal space' and when a selection is made in the group charged with the duty to penetrate (the weakest spermatozoids corresponding to the evolutionists and the amateurs). This comparison is not excessive. The value of 'penetration' (the overcoming of frontiers separating the 'façades' from the internal 'essence') and vertical digging is so rooted in our western culture that this parallel can help to highlight some mechanisms contained in our common thought and in the metaphorical dimension of scientific metalanguages (Montes 2006a).

In this perspective, the theme 'justification' acquires an additional connotation. It is a recurrent theme whose function is to diminish the excessive opposition between the first part of the foreword (defending the virtues of the functionalist method) and the second part (stressing the penetrating power of the single subject into the natives' culture):

In the present state of Ethnography, when so much has still to be done in paving the way for forthcoming research and in fixing its scope, each new contribution ought to justify its appearance in several points. It ought to show some advance in method; it ought to push research beyond its previous limits in depth, in width, or in both; finally, it ought to endeavour to present its results in a manner exact, but not dry. The specialist interested in method, in reading this work, will find set out in the Introduction, Divisions II-IX and in Chapter XVIII the exposition of my points of view and efforts in this direction. The reader who is concerned with results, rather than with the way of obtaining them, will find in Chapters IV to XXI a consecutive narrative of the Kula expeditions, and the various associated customs and beliefs. The student who is interested, not only in the narrative, but in the ethnographic background for it, and a clear definition of the institution, will find the first in Chapters I and II, and the latter in Chapter III. (Malinowski 1922a: xvii)

The oxymoron resulting from the association between the 'objectivity of method' and the 'observation of a single subject' is solved by Malinowski by using a powerful spatial figure which becomes, in itself, a general model for research. In effect, behind the theme of justification, the enunciator proposes some elements characterizing research that belong to the semantic field of space: a path upon which 
one can install future research ("paving the way"), the axiologisation of becoming in terms of limits to overcome ("beyond its previous limits") and some coordinates concerning verticality ("in depth") and surface ("in width"). Space is therefore used as a referent to anchor an imaginary relative to 'progression', 'penetration' and the 'overcoming of limits'. The spatial metaphor is connected to the physical ethnologist's displacement that takes on a central relief in an exotic anthropology: the displacement is in effect essential and preliminary for the ethnologist's work and the subsequent participant (observation) in far-reaching locations is an integral part of his mission.

At this stage, it is necessary to bring to mind that participant observation is itself an oxymoron, a syntagm that associates two semantically conflicting concepts. It is inevitable that anthropologists tend to solve this constitutive oxymoron in one sense or another. In this foreword, the oxymoron is solved by neglecting 'participation' and by focusing on a process of 'de-subjectivation of Otherness': by effacing the native's authority and reducing him to material to observe. 'Observation', 'solidity' and 'passive presence' of the subject-object to observe characterize the discursive order implemented by Malinowski. 'Participation' is restrained to geographical displacement in a faraway country and to amplification of the anthropologist's solitude. To know, an anthropologist has to cope, by himself, with the complications of life in a village. Even though the foreword evokes the help received on location, the people mentioned are not part of the anthropologist's team who is, on the contrary, represented as an individual mastering the local language. Can one really master a language in a couple of years, keeping into account that an anthropologist works with people speaking different dialects? In any case, Malinowski speaks of the language as a means and an instrument to accomplish his research. In this way, he lays value onto the language as means to be used directly for communication, but he tends to consider it more as an instrument than a goal leading to the understanding of culture. Malinowski concludes, then, his foreword by official and ritual thanksgiving to all those people who contributed positively to his research.

By grossly summarizing the analysis of Malinowski's foreword, I would like to stress, among other central features, the exceptional importance of at least three oxymora, even if only one is commonly mentioned by specialists: participant observation. Logically, the 


\section{Stefano Montes}

oxymoron conjugating participation and observation should be solved by a syntagm that highlights firstly 'participation' (above all learning the local language with natives) and secondly careful 'observation' (above all studying the natives). On the contrary, as we have seen, Malinowski combines (and solves) it in his own way. In synthesis, one can say that an 'ideology' of programmation prevails in the solution of oxymora and in the presentation of the ethnologist's work.

On this concern, it is impressive to compare this ideology, subjacent Malinowski's work, with the viewpoint expressed by Clifford Geertz (2000 [1973]) in his foreword to The Interpretation of Cultures. If Malinowski bases his research on the asymptotic and cumulative path of programmation, Geertz, on the contrary, in his fieldwork and in the interpretation of cultures, underlines the punctual and beneficial virtues of coincidence ${ }^{4}$. Each of these anthropologists resorts to a different 'ideology' considering it the only possible way to do fieldwork and to see ethnology. The recourse to one kind of ideology is also, more generally, a strategy to communicate to the public the only manner by which a specialist 'must' (Malinowski) or 'can' (Geertz) do fieldwork and, in the meantime, a manner through which one can affirm the presence (Malinowski) or absence (Geertz) of norms in the ethnologist's work. For Malinowski, it is a question of affirming the presence of normative features and, symmetrically, to endow ethnology with a scientific knowledge. Geertz's concern, on the contrary, consists in cancelling the possibility to conceive a program (theoretical and practical), preliminary to the presence in the field of the ethnologist who, for this same reason, can only proceed by being prey to coincidence, by adjustments and reconsiderations. To be more precise, for Geertz, the casual progression (and even, sometimes, the chaotic drifting) concerns both fieldwork and its communication to his readers:

When, at the beginning of the seventies, I undertook to collect these essays, all of them written the decade before, during the fabled sixties, I was far from

4 By using terms as programmation and coincidence, I make an explicit reference to the model proposed by Eric Landowski according to whom there are four fundamental intersubjective kinds of interaction: programmation (based on regularity and predictability), adjustement (based on reciprocity), coincidence (based on the unforeseeable) and manipulation (based on contractualization) (Landowski 2006). 
clear as to what it was that interconnected them aside from the fact that I had written them. A number were on Indonesia, where I had been working for some years, a number were on the idea of culture, an obsession of mine, others were on religion, politics, time, and evolution, and one, which was to become perhaps the most famous, or infamous (it reduced both Marxists and advanced literati to angry sputtering), was a rather off-beat piece on the deeper meaning of cockfighting among the Balinese. (Geertz 1999: v)

As we have seen, Malinowski's foreword is accurately divided into two parts: in the first part, the enunciator camouflages his presence and ethnology appears as if it was speaking by itself (neutrally and transparently) about scientific foundations and norms; in the second part, the enunciator reveals himself as an ethnologist telling his fieldwork and, through this special assumption of responsibility, implicitly conferring a further and deeper scientific nature to ethnology. Both strategies fulfill a difficult and mirroring task: to assign a scientific value to ethnology and to establish a set of norms to consider as science. Conversely, (already in his incipit) Geertz lays stress, through the singular first person ("I"), on the inseparable syncretism associating a researcher and his field, the enunciator of the foreword and the writer of the text. The intention is to show that a researcher is only apparently a unity, a single person endowed with a clear direction and a definite program. As fragmented and incidental as the researcher in the field, the book is divided in different chapters which have no unit or global conception. To show it, the enunciator focuses on a precise theme: the lack of interconnection of the essays. More specifically, the enumeration is the stylistic figure that becomes, on this concern, the instrument to underline the variety of themes approached in the essays and the absence of a common lead. All these features (actantial syncretism, focalisation on the absence of interconnection, recourse to enumeration) indicate that, in his perspective, coincidence is all pervading in the performance of an ethnologist who cannot follow the principles of programmation. Since his research was the result of coincidences, his book also lacks interconnection and is the result of coincidence (and vice versa). The rhetorical question clears and underlines this 'non-connection' between incidental research and incidental chapters in the book: "Did they add up to anything: a theory? a standpoint? an approach?" (Geertz 2000b: v).

The question closes the segment concerning the incipit and, in the meantime, opens a new important section in which the enunciator 
starts telling a story with a sender (the editor) who has also the role of a helper (the editor), an object of value ("a position" and "a slogan"), a subject potentially charged with a performance ("I"), but actually devoid of the necessary competence. Paradoxically, by writing the theoretical essay introducing and 'connecting' all the other articles of the book, the subject passes from a situation of imbalance (lack) to a situation of balance (solution of lack). This classical transformation, foreseen in simple fairy tales and in more complex literary stories, poses here a problem since the cognitive acquisition on the part of the subject is contradictory. How can an author-subject justify a theoretical essay if his perspective is based on the affirmation of coincidence and on the absence of a theory? By telling a story in which the subject of performance acquires the competence (that makes him ready for cognitive action) through a manipulation showing that even a theoretical essay is the fruit of a coincidence and not of a program intentionally conceived:

I didn't even have a title for the thing, much less a rationale. I had thought to call it Meaning and Culture, but the lamented Marvin Kessler, who was my editor at Basic Books, and whose idea it was in the first place to collect the essays, rightly did not think much of that - the evasion was too obvious, and the phrasing uninspired - and he urged me to write an extended analytical introduction stating my general position. I said I didn't know that I had one. He said (there were editors in those days): "You'll find one." And thus I produced "Chapter I. Thick description: Toward an Interpretive Theory of Culture," and discovered both a position and a slogan I have been living with since. (Geertz 2000: v)

Geertz acquires a 'theoretical awareness' by interacting with his editor who helps him to find out something he had previously ignored: a position and a slogan. One might say that Geertz passes from an ideology of coincidence to an ideology of manipulation ("You'll find one") and, for some aspects, to an ideology of adjustment ("There were editors in those days"). What is more impressing is that Geertz, by passing from one position to the other, does not speak of interaction with the native. The kinds of interaction that concern him are with his editor and with his writing.

This backward order of things - first you write and then you figure out what you are writing about - may seem odd, or even perverse, but it is, I think, at least most of the time, standard procedure in cultural anthropology. Some 
pretenders to high science and higher technique aside, we do not start out with well-formed ideas we carry off to distant places to check out by means of carefully codified procedures systematically applied. We go off to those places, or, increasingly these days, ones closer by, with some general notions of what we would like to look into and of how we might go about looking into them. We then in fact look into them (or, often enough, look instead into others that turn out to be more interesting), and after doing so we return to sort through our notes and memories, both of them defective, to see what we might have uncovered that clarifies anything or leads on to useful revision of received ideas, our own or someone else's about something or other. (Geertz 1999: v-vi)

If Malinowski is more concerned with the problem of 'observation' than 'participation', Geertz is more concerned with the problem of 'writing' (and justifying a position) than interacting with his Other. As a matter of fact, both anthropologists neglect the active role that natives play in the construction of interaction and acquisition of knowledge. For Malinowski, the opposition existing between observation and participation is solved in favour of observation. For Geertz, the opposition existing between the process of writing and the preliminary idea is solved in favour of writing. Rather than outlining a hypothetical process of research, in its whole and its linearity, as a syntagmatic development in which some segments can prevail upon others or precede others (for example: selection of a problem $\rightarrow$ bibliographic research $\rightarrow$ first theoretical hypothesis $\rightarrow$ fieldwork research $\rightarrow$ participation $\rightarrow$ observation $\rightarrow$ fieldwork notes $\rightarrow$ interpretations $\rightarrow$ structurations $\rightarrow$ writing), Geertz prefers opposing, by using dichotomies, those who follow a "standard procedure" and the "pretenders to high science and higher technique": the value of the first ones is emphasized while the value of the second ones is cancelled.

As we have seen, Malinowski is in conflict with the Evolutionists, but he cannot say it overtly. Geertz cannot say what kind of anthropology he discredits, but, if one reads the whole foreword, one might suppose that Geertz thinks of Structuralism in negative terms.

The writing this produces is accordingly exploratory, self-questioning, and shaped more by the occasions of its production than its post-hoc organization into chaptered books and thematic monographs might suggest. (Geertz 2000b: vi) 
Therefore, this foreword written by Geertz presents ethnologists as men without certainties in their work, men caught in the "web" of meanings they have themselves produced. Even though an ethnologist has acquired competences that make him suited for fieldwork (and for interpretations of cultures) he has to enact a series of interactions more with his editor (and his own texts) than with the real and true Others: the natives. In the case of Geertz, the ethnologist's work is reduced to multiple forms of writing: (1) writing as conclusion of a research, (2) writing as introduction to a book, (3) writing as questioning of the anthropologist. In sum, these are all different ways of writing focusing on the return to the ethnologist's Self, to his subjectivity devoid of any reference to what is usually understood as the real object of study: culture and Otherness.

The paradox is that, to advance in the crumbling of any form of programmation, Geertz produces a discourse based on dichotomies that reminds us of the binary oppositions used by Structuralists to speak of myth. As in the previous fragments ("standard procedure" $v s$ "pretenders to high science"; "first you write" vs "then you figure out"), also in this part of the foreword, Geertz proceeds by using bipolar couples: for example, "occasions of its production" vs "posthoc organization".

This concluding phase of work - concluding until we go off somewhere again, or turn to other concerns - is consequently both crucial and a bit of sleight-of-hand. Crucial, because without it we are left with an assortment of vignettes and aperçus, fragments in search of a whole. Sleight-of-hand because it presents what is in fact a trailing construction as though it were a deliberated thesis happily confirmed. Anthropological arguments - and The Interpretation of Cultures is most definitely such an argument - are like excuses, made up after the stumblings that make them necessary have already happened. (Geertz 2000b: vi)

From the aspectual viewpoint, the ethnologist's work is formulated by Geertz as if it was a process being continuously re-elaborated and reproduced. If coincidence is important for Geertz, writing, in its multiple forms, is determining: in the initial and in the conclusive phase of fieldwork. Stressing the multiplicity of writing is a manner to reject unity and homogeneity. 'Coincidence' and 'process' are associated in Geertz's discourse to disrupt any form of static category and any form of preconceived essence (in favour of multiplicity and 
dynamism). Even the conclusion of a work is considered as a postponement to another work, a dynamic non-conclusion. By this strategy, it is affirmed not only the quality of coincidence but also the importance of the imperfective process of the never-ending work. Slowly proceeding by using bipolar couples, positively stressing one term and negatively posing another one, Geertz amplifies the force of coincidence by reversing any possible cause and effect relationship: (1) between the essays of his book, (2) between the idea (that should precede) and its writing, (3) between a theoretical essay (that should introduce) and the other essays.

In any case, whether forethought or afterthought, general statements, such as that I was so fortunately pressed into (fortunately for the direction of my work and for its impact) in the "thick description" piece, make sense in anthropology as commentaries on particular inquiries, such as those which compose the rest of the book. Detached from them they seem mere promissory notes, empty boxes, possible possibilities. The pieces on a disrupted Javanese funeral, on Balinese conceptions of time and identity, on shadow plays or Indic states, and yes, on cockfighting and the closet melodrama of animalised status rivalry, are what give the more general statements, not just in the thick description piece, but in "Religion as a Cultural System," "Ideology as a Cultural System," or "The Growth of Culture and the Evolution of Mind," whatever suggestiveness and plausibility they might have. Despite my initial uncertainties, the book is a book, the chapters are chapters, and the whole has a certain informing rhythm. (Geertz 2000b: vi)

As a matter of fact, to elaborate a discourse of multiplicity and noncausality, Geertz cannot avoid building on some categories and generating hierarchies. Even though Geertz tries to disrupt all the logical relationships between cause and effect, he is compelled to admit that he has a position and the book has a coherence. This final acceptance is tautological: "the book is a book, the chapters are chapters". This is in harmony with the isotopy founding the more general discourse of Geertz's foreword: the justification, in any possible way, even resorting to tautology, of a work that would like to be free of constraints and essentially based on concrete situation and on particular coincidences.

Even though Geertz's discourse of justification is more evident, there is anyway behind it a more powerful discourse denying all efforts accomplished by Geertz to affirm non-causality and multiplicity: the opposition between the whole and the part, unity and 
fragmentation, connection and separation. If Malinowski, to give a scientific foundation to ethnology, has to fix some criteria upon which to build the value of science, Geertz, to affirm a discourse of multiplicity and non-causality, has to insist on some features that give a solid foundation - exactly what he wanted to conjure up - to his discourse. Geertz concludes his foreword by debating himself in the web he himself created: on one hand, by stressing the importance of dynamic postponement (general research conceived as non terminative process) and, on the other hand, by founding the final value of a goal (his own research anticipating the "hares" to be chased by future ethnologists). One might malignantly suppose that the intention to crumble all general and fixed categories is the preliminary act to affirm the value of a single researcher: the value of his own specific research.

It is now more than a quarter of a century since it was published. It's republication now, after so much has happened, both in the world and in anthropology, is perhaps a sign that some of the hares I started then have turned out to be worth chasing. I am, in my case, still chasing them. (Geertz 2000b: vi)

By comparing Malinowski's foreword and Geertz's foreword, we can say that a question concerning the enunciators consists in the way one can lay a discipline with scientific value (Malinowski) and in the way one can highlight a specific and incidental performance of a researcher (Geertz). Fundamentally, both enunciators resort to stories that frame complex argumentations.

What kind of story tells Malinowski (and the enunciator who replaces him in the text)? In his foreword, at least two superposing stories are being told: the first one is the tale of the performance of a subject endowed with competences (Malinowski in the Trobriand Islands) and a discipline possessing a positive knowledge (ethnology); the second one is the tale of exchanged message (with relative sanction and counter-sanction) between an enunciator and addressee, between an enunciator who has to make the first tale believable and the addressee who has to confirm the validity of this message. As we have seen, both stories, distinguished from the viewpoint of analysis, are superposing and referring one another, in the text, in order to build the scientific nature of ethnological knowledge. 
As far as Geertz's foreword is concerned, we can remark that the enunciator has recourse to two stories: the first one concerns the interaction between Geertz and his editor; the second one, larger and including, concerns the reformulation of the logical relationship of causality and reaffirmation of coincidence. The paradox is that, for an interpretativist as Geertz, he tells in his foreword, following a structuralist manner, a tale in which the discursive categories are laid by opposite couples. Equally paradoxical, to give value to coincidence (logically connected to context and 'being in situation'), the enunciator neglects the question of experience and stresses the importance of writing in its multiple forms. Finally, in Geertz's foreword a binary discursive epistemology and a style of thought that privileges the nonterminative and imperfective process are combined.

As far as I am concerned, the comparison of two forewords is a premise to a larger project based not only on similarities and differences existing between the textual genres of two great anthropologists (see, for example, Boon 1983 concerning Frazer/Malinowski). My project is also an exploration of the modalities according to which, in the ethnologist's work, some questions are interrelated and reformulated: the communication-interaction between actants and actors, the invention-application of metalanguages and the intercultural translation of concepts and processes. The starting hypothesis is that the performance of an ethnologist (or an anthropologist, the distinction being at this point useless) takes the amplitude of a syntagmatic process containing (and developing) the paradigmatic modelization of a discipline, of the society to which the ethnologist belongs and of the society to which the Others belong (Montes 2006b). In this perspective, the narrative intrigue of the evenemential and cognitive dimension, besides being an integral part of the effective ethnologist's work, can constitute, read in the light of semiotic analysis, a real and true epistemological configuration in which the features characterising the ethnologist's belonging (and more generally, the native-function) acquire a central meaning (Montes 2006a). 


\section{References}

Boon, James A. 1983. Frazer/Malinowski and the semiotics of the monograph. Semiotica (Special issue: Signs in the Field: Prospects and Issues for Semiotic Ethnography) 46(2/4): 131-149.

Buttitta, Antonino 2003. Escursioni intorno all'Io. In: Scarduelli, Pietro (ed.), Antropologia dell'Occidente. Roma: Meltemi, 41-68.

Foucault, Michel 1971. L'ordre du discours. Paris: Gallimard.

- 1994 [1969]. Qu'est-ce qu'un auteur?. In: Dits et écrits, vol. 1. Paris: Gallimard, 789-821.

Geertz, Clifford 1988. Works and Lives. The Anthropologist as Author. Stanford: Stanford University Press.

- 2000 [1973]. The Interpretation of Cultures. New York: Basic Books.

— 2000b. Preface to the 2000 edition. In: Geertz, Clifford 2000 [1973]: v-vi.

Greimas, Algirdas Julien 1983. Du sens II. Paris: Seuil.

Kilani, Mondher 1990. Les anthropologues et leur savoir : du terrain au texte. In: Adam, Jean Michel; Borel, Marie Jeanne; Calame, Claude; Kilani, Mondher (eds.), Le discours anthropologique. Description, narration, savoir. Paris: Klincksieck.

Landowski, Eric 2006. Les interactions risquées. (Nouveaux Actes Sémiotiques 101/102/103.) Limoges: Pulim.

Lévi-Strauss, Claude 1988. De près et de loin. Paris: Odile Jacob.

Malinowski, Bronislaw 1922a. Foreword. In: Malinowski 1922b: xv-xviii.

- 1922b. Argonauts of the Western Pacific. An Account of the Native Enterprise and Adventure in the Archipelagos of Melanesian New Guinea. With a Preface by Sir James Frazer. London: Routledge and Kegan.

Miceli, Silvana 1990. Orizzonti incrociati. Il problema epistemologico in antropologia. Palermo: Sellerio.

Montes, Stefano 2000-2001. Tradurre le culture: strategie dei testi, strategie degli antropologi. Archivio Antropologico Mediterraneo 3/6(3-4): 35-51.

- 2005a. Enoncer soi-même, énoncer le terrain. La deixis des anthropologues et le métalangage des linguistes. In: Monticelli, Daniele; Pajusalu, Renate; Treikelder, Anu (eds.), De l'énoncé à l'énonciation et vice versa. Regards multidisciplinaires sur la deixis, vol. 1. (Studia Romanica Tartuensia 4.) Tartu: Tartu University Press, 141-169.

- 2005b. Manuali, “fieldwork”, migranti. Passi per un'antropologia semiotica delle culture. In: Ruta, Maria Caterina (ed.), Le parole dei giorni. Scritti per Nino Buttitta. Palermo: Sellerio, 978-1011.

- 2006a. Écrire une anthropologie, écrire une philosophie. F. Héritier et G. Deleuze en regard. In: Ljalikova, Aleksandra (ed.), La complexité comme principe et raison de la recherche balte en Sciences Humaines. (Synergies, Pays Riverains de la Baltique 3.) Tallinn: Gerflint, 157-174.

- 2006b. Is intra-reception possible? The literatures of anthropologists, Marc Augé and Otherness. In: Dynamiques de réception de la littérature mondiale - Dynamics of the Reception of World Literature, vol. I. (Interlitteraria 11.) Tartu: Tartu University Press, 246-260. 
Taverna, Licia 2006. La préface comme genre discursif. Dire et Avant-dire dans Nadja de Breton. In: Ljalikova, Aleksandra (ed.), La complexité comme principe et raison de la recherche balte en Sciences Humaines. (Synergies, Pays Riverains de la Baltique 3.) Tallinn: Gerflint, 175-189.

Valeri, Valerio 2002. Il futuro degli antropologi. In: Brutti, Lorenzo; Paini, Anna (eds.), La terra dei miei sogni. Esperienze di ricerca sul campo in Oceania, Roma: Meltemi, 28-47.

\section{Просто предисловие? Малиновский, Гирц и антрополог как абориген}

Сквозь призму семиотического анализа нарративная интрига работы антрополога (т.е. ее событийное и когнитивное измерения) обнажает эпистемологическую конфигурацию, заключающуюся в некторых центральных проблемах антропологии: общение и взаимовлияние антропологов и других участников коммуникации, то, как антропологи изобретают и применяют метаязыки, и последовавшй после изобретения метаязыка межкультурный перевод понятий и процессов. Для анализа названной конфигурации я сравниваю два предисловия: Малиновского и Гирца. В предисловии Малиновского имеются две совпадающие истории. Во-первых, история о действующем субъекте, только что наделенным профессиональной компетенцией (этнолог), и о научной дисциплине, которая обладает более современным и позитивистским знанием (функционалистская этнология). Во-вторых, мы видим симметричный обмен сообщениями (вместе с прилагающимися санкциями и противосанкциями) между высказывающимся (задание которого - заложить основы своей научной дисциплины) и адресатом (который должен принять решение по поводу обоснованности сообщений). Для сооружения основ своей науки высказывающийся имплицитно выдвигает эпистемологию, основывающуюся на определенных ценностях («вторжение», «прорыв», «преодоление ограничений»), предпочитая пространственную метафору и кумулятивный аспект процесса.

В предисловии Гирца мы находим две отдельные истории. Вопервых, история, касающаяся общения между Гирцем и его редактором, чтобы оправдать герменевтическую позицию исследователя. Вторая история гораздо объемнее и охватывает перевертывание каузальных отношений во имя оправдания важности случайности. Если в предисловии Малиновского названные истории используются для нового определения программных принципов (комбинация «трех оксюморонов» и «дисконтинуальности»), посредством которых 
этнология могла бы приобрести научный характер и новые основы, то Гирц выделяет в своем предисловии именно «совпадение» и «письмо» в их всевозможных формах и комбинирует парадоксальным образом (для сторонника интерпретативности) бинарную дискурсивную эпистемологию с образом мышления, предпочитающим неконечные и несовершенные процессы.

\section{Lihtsalt eessõna? Malinowski, Geertz ja antropoloog kui pärismaalane}

Semiootilise analüüsi prisma läbi paljastab antropoloogi töö narratiivne intriig (st selle sündmuslik ja kognitiivne dimensioon) epistemoloogilise konfiguratsiooni mõnede antropoloogia kesksete probleemide ümber: antropoloogide ning teiste osapoolte vaheline suhtlus ja vastasmõju, see, kuidas antropoloogid leiutavad ja rakendavad metakeeli, ning metakeele leiutamisele järgnev mõistete ja protsesside kultuuridevaheline tõlge. Nimetatud kompleksi analüüsimiseks võrdlen ma kahte eessõna: ühte Malinowskilt ja teist Geertzilt. Malinowski eessõnast leiame kaks kattuvat lugu. Esiteks, lugu toimivast subjektist, keda on värskelt õnnistatud ametialase kompetentsiga (etnoloog), ning teadusvaldkonnast, mis valdab tänapäevasemat ja positiivsemat teadmist (funktsionalistlik etnoloogia). Teiseks näeme lausuja (kelle ülesandeks on püstitada oma teadusdistsipliini alustalad) ja adressaadi (kes peab otsustama sõnumite kehtivuse üle) vahelist sümmeetrilist sõnumitevahetust koos sinnakuuluvate sanktsioonide ja vastusanktsioonidega. Oma teaduse alustalade püstitamiseks pakub lausuja implitsiitselt välja teatud väärtustel ("sissetungimine", "edasiminek", "piirangute ületamine") põhineva epistemoloogia, eelistades ruumimetafoori ning protsessi kumulatiivset aspekti. Geertzi eessõnas aga leiame kaks eraldiseisvat lugu. Esiteks lugu, mis puudutab suhtlust Geertzi ja tema toimetaja vahel (mitte suhtlust pärismaalastega), et õigustada uurija hermeneutilist positsiooni. Teine lugu on märksa ulatuslikum ning hõlmab põhjuslikkussuhete pea peale pööramist selleks, et kinnitada juhuslikkuse tähtsust. Kui Malinowski eessõnas kasutatakse nimetatud lugusid selleks, et defineerida uuesti teatud programmilisi põhimõtteid ("ebapidevus" ja "kolme oksüümoroni" kombinatsioon), mille kaudu etnoloogia võiks omandada teadusliku iseloomu ja uued põhialused, siis Geertz väärtustab oma eessõnas just "kokkusattumuslikkust" ja "kirjutamist" nende kõikvõimalikes vormides ning kombineerib (tõlgenduslikkuse pooldajale) paradoksaalsel moel binaarse diskursiivse epistemoloogia ja mõtteviisi, mis väärtustab mittelõplikke ja mittetäielikke protsesse. 